\title{
Pumped Transfer of Liquefied Gases
}

\author{
Felix Ochsner*
}

\begin{abstract}
The transfer of liquefied gases comprises a special hazard potential. Therefore special equipment and expertise is necessary. It is not possible for every HazMat base to hold its own equipment. Therefore in Switzerland the Flüssiggaspikett der Ostschweiz and DSM Nutritional Products, Sisseln, can be called out to provide help if incidents with liquefied gases occur. A case study of a real mission is presented. Furthermore technical specifications of key items and the experience of the author are provided.
\end{abstract}

Keywords: Ammonia · Hazardous materials technician · Railway accident · Training facility · Transfer of liquefied gases

\section{Introduction}

Liquefied gases are often transferred and/or stored in stationary facilities in large quantities. If incidents involving liquefied gases occur, the emergency services deployed must take special safety aspects into account and require specialised equipment to deal with the situation. The number of HazMat Units that can be called out to provide help if incidents with liquefied gases occur is therefore very small. In Switzerland these comprise the HazMat Unit of DSM Nutritional Products (DNP) in Sisseln, for the past six years, and the Fliussiggas-Pikett der Ostschweiz (Eastern Switzerland Liquefied Gas Emergency Service) for the past two years. The specialised equipment used by these two units is compatible.

Our company, the DNP production site at Sisseln, stocks large quantities of liquid ammonia. In order to be prepared for any emergencies that might occur, our HazMat Unit has therefore been provided with the equipment necessary for handling liquefied

\footnotetext{
${ }^{*}$ Correspondence: F. Ochsner

DSM Nutritional Products

Hauptstrasse 4

$\mathrm{CH}-4334$ Sisseln

Tel.: +41628662497

Fax: +4162 8662075

E-Mail: felix.ochsner@dsm.com
}

www.dsmnutritionalproducts.com gases. This was done based on our own expertise together with advice from BASF, which could call on some experience, having been equipped for liquefied gas incidents for several years.

Our HazMat Unit specialists have had regular drills involving the use of this equipment, not only as dry runs but also 'live' with liquid ammonia. We have used the experience gained with these exercises to continually update and optimise the checklists and equipment.

Two years ago we were able to demonstrate our operational readiness in terms of both personnel and equipment when a rail tank wagon containing liquid ammonia was derailed in a shunting mishap at Brugg, and its contents had to be transferred by pump following careful preparation work.

\section{Hazard Potential}

The expression 'liquefied gases' is used in this article for all gases liquefied under pressure at ambient temperature, such as propane, butane, ammonia, carbon dioxide, chlorine and ethylene oxide.

Liquefied gases represent a potential hazard that must not be underestimated, not only during storage but especially when they are transported. Many properties (toxicity, combustibility, colour, smell) of the various liquefied gases can vary considerably, but they all have the following in common:

- They can be liquefied under pressure.

- In the vessel they are under pressure, which increases when the vessel is heated.
- When they evaporate, the volume of gas is many times that of the liquid (propane 260 times; butane 220 times).

- They are heavier than air.

- They can inflict cold burns.

- They can cause suffocation.

- When pumped, they tend to cavitate and therefore require special pumps.

- With liquefied combustible gases the danger also exists of a 'boiling liquid expanding vapour explosion' (BLEVE) occurring.

These points and many other safety aspects must be taken into account should an incident occur. The following description of one such occurrence is intended to illustrate - or at least address - the questions to be clarified when dealing with an incident. It must be acknowledged that the 'chaos phase' of this particular incident was very short, since it was quickly established that there was no immediate danger to the emergency personnel or to local residents. The planning phase allowed enough time for appropriate technical and organisational preparations to reduce the residual risk involved in the pumped transfer operation to an acceptable minimum.

\section{Description of Incident}

On the morning of October 3, 2001, a rail tank wagon loaded with some 20 to ammonia was derailed on an industrial siding as a result of operator error (Fig. 1). The derailed wagon came to rest on the ballast immediately next to the track and was not damaged. Despite this, the railway manage- 


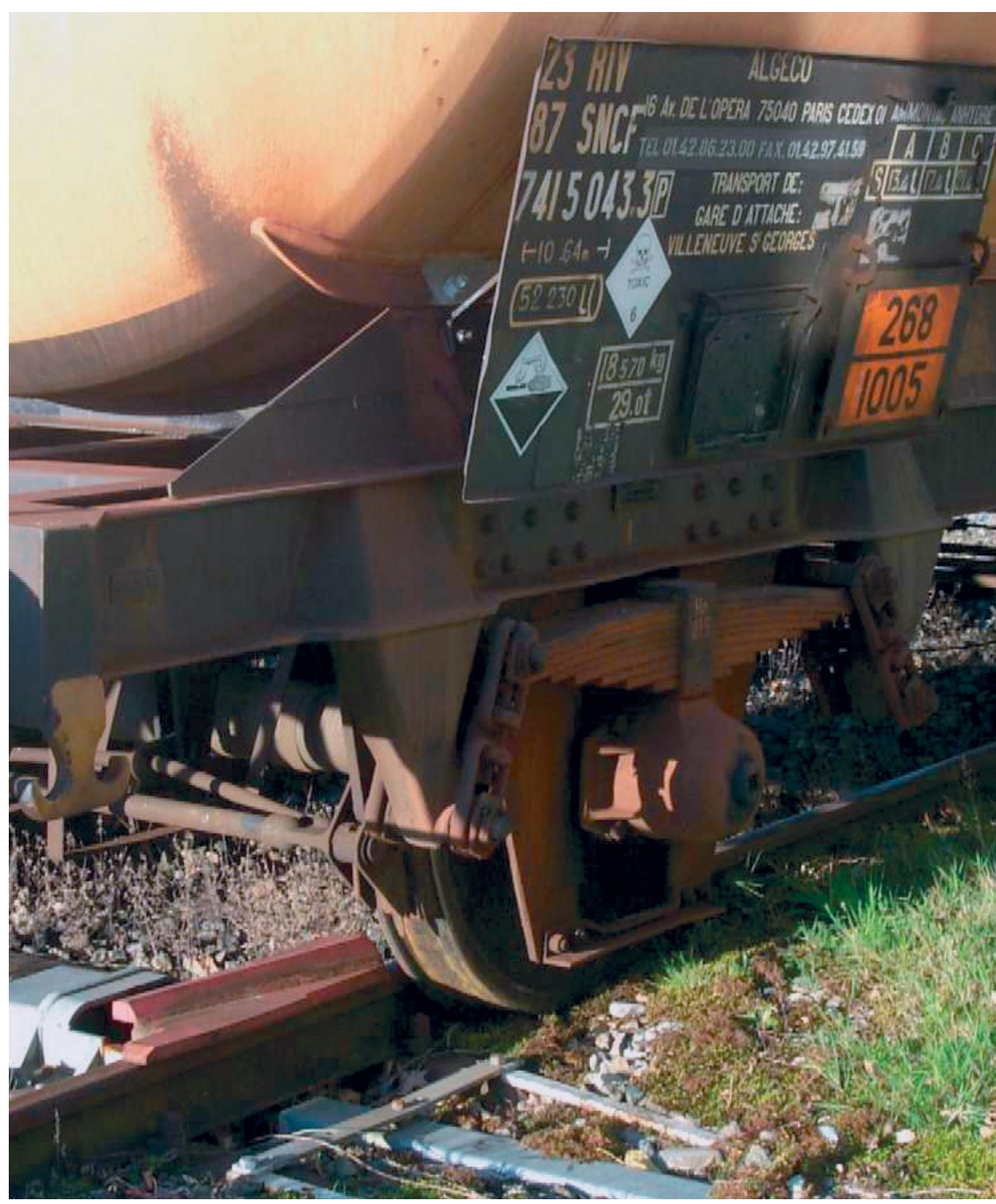

Fig. 1. Derailed wagon with some twenty tonnes of ammonia. The stumbling block as cause of the derailment is visible; next to the wheel.

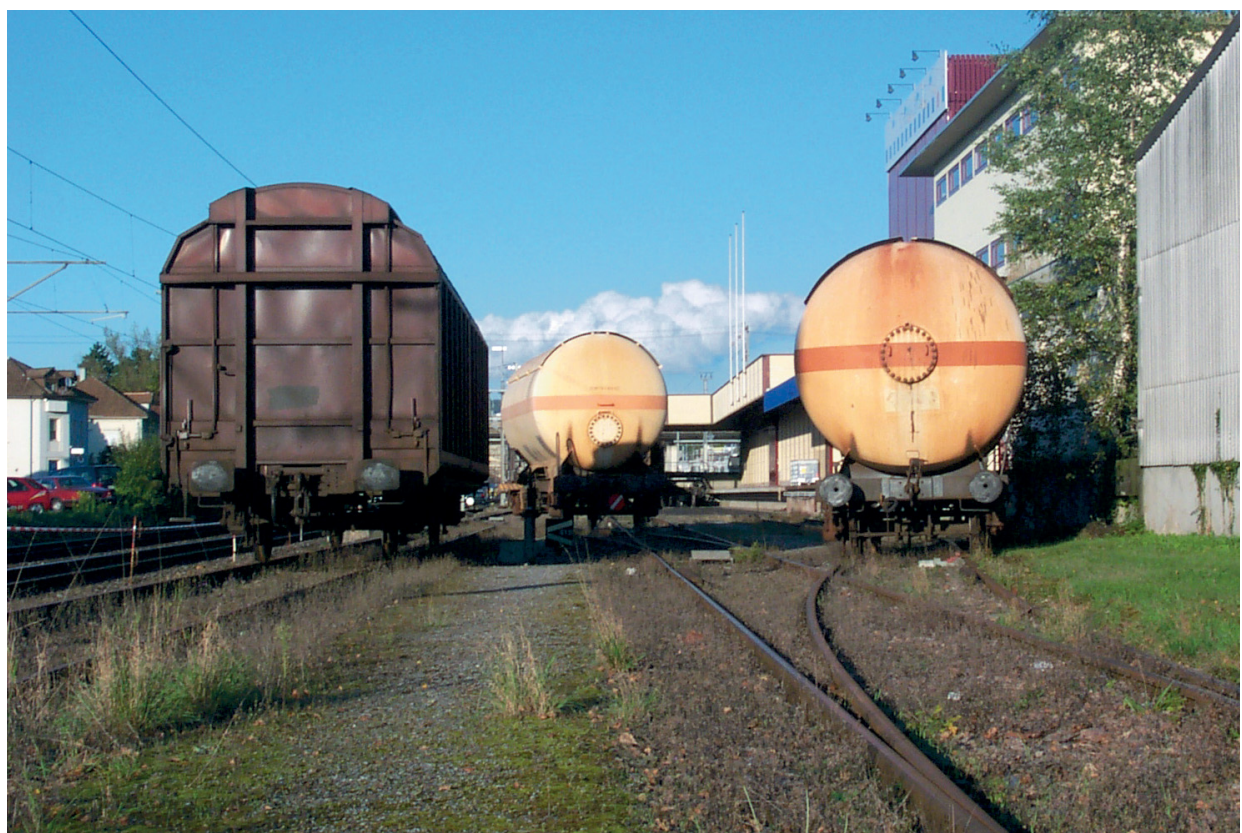

Fig. 2. General overview with railway line Zurich-Bern left, industrial buildings, derailed wagon right and recovery wagon in the middle. ment would not accept the responsibility for lifting the full tank wagon back onto the rails. It was therefore necessary to empty the wagon before doing so.

A meeting was held at the site of the incident to discuss the various possibilities for a recovery operation, the advantages and disadvantages of each option being compared and evaluated. At this initial meeting, but also during the subsequent recovery operation, the overall command fell to the officer in charge from the Central Fire Brigade, as set out in cantonal regulations. Other organisations involved were each represented by one person on the advisory staff of the officer in charge.

The following organisations were represented at the initial meeting: railway, police, Brugg Central Fire Brigade, EMS DOTTIKON HazMat Unit, and DNP Sisseln HazMat Unit, plus a chemical consultant from Chemia Brugg, the company to which the ammonia was to have been delivered. Coordination with the specialists at the Cantonal Office of Environmental Protection, the suppliers of the ammonia tank wagon and the Flüssiggas-Pikett der Ostschweiz was by telephone.

Among the points considered when coming to a decision were the following:

- The industrial siding is located some $10 \mathrm{~m}$ away from the Zurich-Brugg-Bern railway line. (Fig. 2).

- Beyond the railway line a main road runs parallel to it.

- The first houses of a residential area are located directly on this main road.

- The industrial buildings immediately next to the industrial siding are only occupied during the daytime.

- A piping line to convey the wagon contents to the Chemia tank farm would have to be about $200 \mathrm{~m}$ long.

- Suitable road tankers could reach the site that day if required.

- It would take an empty rail tank wagon at least $12 \mathrm{~h}$ to reach the site.

- Rail traffic would have to be stopped during the pumped transfer operation.

- The capability to stop all road traffic quickly if necessary would have to be ensured.

- Local residents would need to be oriented about the necessary action to be taken during the pumping operation.

- A time of some 10-12 h was estimated for preparing and carrying out the pumped transfer operation.

- Fire protection would have to be ensured during the entire pumping operation.

- The empty derailed tank wagon could be lifted back onto the rails even when rail traffic is running again on the main line. 
The following procedure was decided upon:

- A replacement empty rail tank wagon to be sent to the site from the Lonza Company in Visp.

- The pumped transfer operation to be carried out in the night of October 4, 2001.

- The period of time during the night from 23.30-05.00 during which there are normally no passenger trains running was to be used for the pumped transfer operation.

- The various tasks were assigned to the five organisations involved in the operation as follows:

Brugg Central Fire Brigade: Overall command of operation, coordination with the authorities, fire protection, road safety measures, decontamination facility, logistics.

DNP Sisseln HazMat Unit: Illumination of the incident site, pumped transfer with liquefied gas pump, HazMat zone demarcation, disposal of the ammonia solution resulting from the operation.

EMS DOTTIKON HazMat Unit: Measurement of hazardous substances in the atmosphere and support with site illumination.

Brugg Police: Informing local residents, road traffic control.

Swiss Federal Railways: Diversion of rail traffic, switching off power to overhead contact lines and earthing them, lifting the empty derailed tank wagon back onto the rails.

Preparations for the actual pumped transfer operation could begin in the late afternoon of the day after the derailment:

- The specialists in our HazMat Unit marked out the incident zone. On the basis of a detailed checklist (Table 1), they installed the required hose connections between the two tank wagons and the pump and also to the vessels filled with water into which the residual contents would have to be discharged and the system rinsed out on completion of the pumped transfer operation.

- Brugg Fire Brigade cordoned off a large area around the site of the incident, set up the decontamination facility and made the extensive preparations necessary for fire protection. These included setting up and testing the spray pattern of the monitors necessary to contain any leaking gas with a water spray, and installing a powerful blower. Additionally, dry powder system hoses were placed in readiness.

The following notes (Table 2) - taken from the incident logbook but drastically condensed - outline the operation. All indi-
Table 1. Checklists for incidents involving liquefied gases Preparations (normal fire protection equipment)

1. Situate pump (1) at correct location.

2. Select adequate lengths of pressure hose (2) and hold in readiness.

3. Hold connecting flange (3) for derailed tank wagon in readiness.

4. Hold connecting flange (4) for recovery tank wagon in readiness.

5. Hold gas balance line (5) in readiness.

6. Hold connecting flange (6) for gas balance line to derailed tank wagon in readiness.

7. Hold connecting flange (7) for gas balance line to recovery tank wagon in readiness.

8. Make discharge hose for gas release (8) ready. 2-inch hoses from HazMat Unit appliance.

9. Make valves and fittings ready for recovery tank wagon adapter (9). In addition Nos. 83 and 25 from HazMat Unit appliance.

10. Take off cover of vacuum drum (10), remove ball, modify and fill with water.

11. Make water hose (11) ready, 1-inch hose from HazMat Unit appliance.

12. Make collector tank (12) from HazMat Unit appliance ready and fill with water.

13. Make nitrogen line (3) from HazMat Unit appliance ready.

14. Make electrical cables for pump ready and unreel from HazMat Unit appliance.

15. Hold pressure gauge ready but do not fit yet.

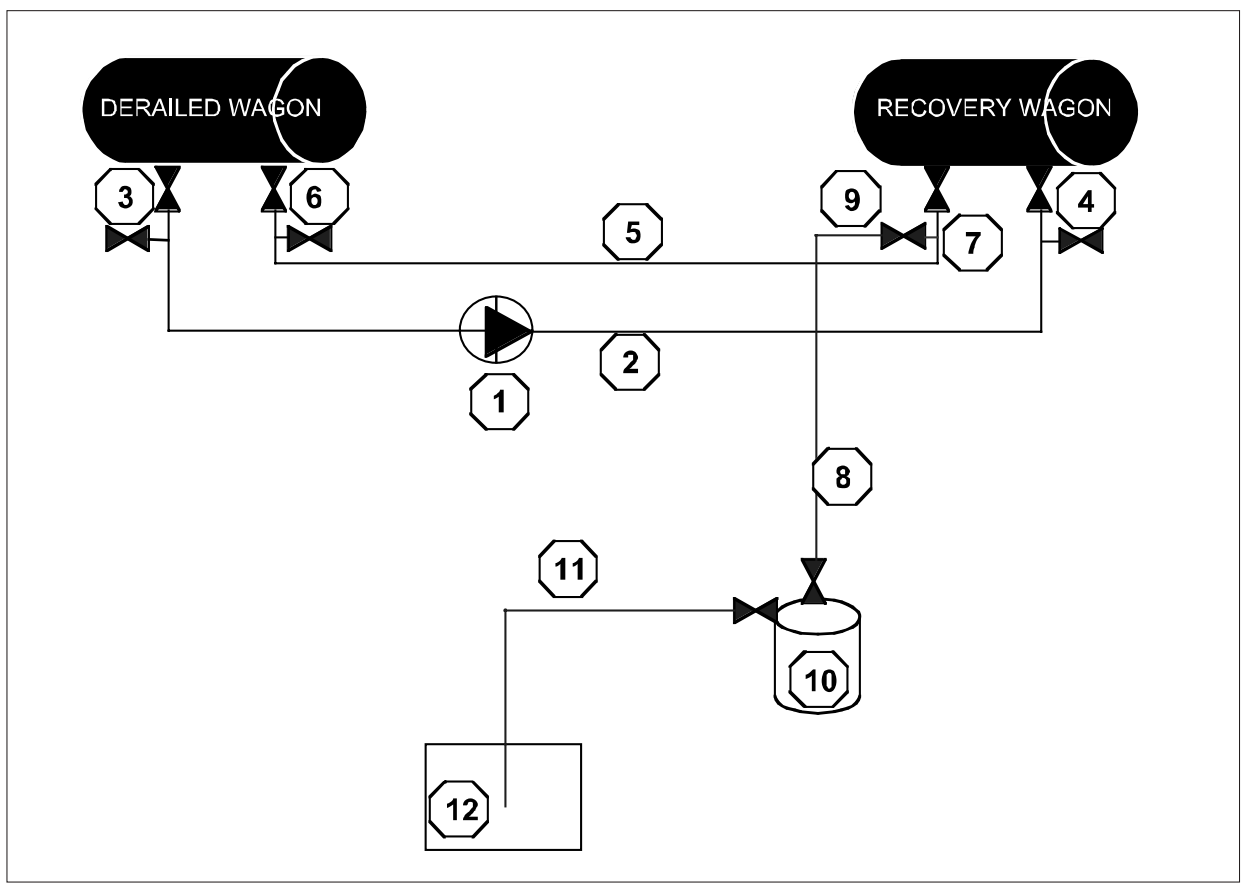

vidual procedures were carried out on the basis of prepared checklists and could be accomplished without any difficulties worth mentioning.

\section{Equipment}

A 2-man team (front officer and assistant) wearing heavy-duty full protective suits and long-duration compressed air breathing apparatus supervised the operation directly on site. The work required around the two tank wagons and the liquefied gas pump was also performed directly by this team, with the help of the appropriate checklist for each operation.

The other Fire Brigade and HazMat Unit personnel were equipped with their fire protection clothing and had compressed air breathing apparatus ready for 
Table 2. Timeline taken from the incident logbook

\section{Thursday, October 4, 2001}

\begin{tabular}{|c|c|c|}
\hline $2320 \mathrm{hrs}$ & Railway & Contact lines locked out and earthed \\
\hline $2330 \mathrm{hrs}$ & Brugg safety officer & Cordons and traffic marshals in position \\
\hline $333 \mathrm{hrs}$ & $\begin{array}{l}\text { HazMat Unit officer } \\
\text { in charge }\end{array}$ & Operation can begin \\
\hline 336 hrs & HazMat Unit front officer & Derailed wagon: main valve open \\
\hline 337 hrs & HazMat Unit front officer & Recovery wagon: main valve open \\
\hline $338 \mathrm{hrs}$ & HazMat Unit front officer & Pressure at pump 7 bar; pressure equalisation flow \\
\hline 340 hrs & HazMat Unit front officer & $\begin{array}{l}\text { Gas balance line opened at both ends; stuffing } \\
\text { box of derailed wagon valve tightened }\end{array}$ \\
\hline 342 hrs & HazMat Unit front officer & Pump running \\
\hline $345 \mathrm{hrs}$ & Measurement group & Everything OK \\
\hline $346 \mathrm{hrs}$ & HazMat Unit front officer & $\begin{array}{l}\text { Operation going OK; pressure in pump line } 8 \text { bar; } \\
\text { pressure in gas balance line } 6 \text { bar; no valves leaking }\end{array}$ \\
\hline $349 \mathrm{hrs}$ & HazMat Unit front officer & $\begin{array}{l}\text { Level in derailed wagon cannot be determined with } \\
\text { thermal imaging camera }\end{array}$ \\
\hline
\end{tabular}

Friday, October 5, 2001

$0013 \mathrm{hrs}$ HazMat Unit officer
in charge

$0014 \mathrm{hrs}$ Measurement group

0015 hrs Brugg officer in charge

$0021 \mathrm{hrs}$ HazMat Unit front officer

0202 hrs HazMat Unit front officer

0210 hrs HazMat Unit front officer

0211 hrs HazMat Unit officer in charge

0223 hrs HazMat Unit front officer

0224 hrs HazMat Unit officer in charge

0226 hrs Measurement group

0321 hrs HazMat Unit officer in charge

0324 hrs HazMat Unit front officer

0330 hrs Brugg officer in charge

0333 hrs Brugg officer in charge

0400 hrs Brugg officer in charge

0402 hrs HazMat Unit officer in charge

0410 hrs Railway

0415 hrs Brugg officer in charge

0442 hrs Railway

0445 hrs Brugg officer in charge
Team in full protective clothing and front officer relieved

\section{Everything OK}

Fire protection team relieved

Everything OK

Gas balance line closed

Pumped transfer finished

Connections set up for nitrogen purge

Nitrogen off. All valves closed; team with full protective clothing and front officer relieved

Connections set up for gas release into water tanks

Ready for measurements at collector tank

Pressure in discharge line 0 bar; line ready for water

Water to rinse line; rinse begins

Dry powder system and transfer line (2) withdrawn

Rail track closed to Fire Brigade personnel and released for railway use

Measurement group and monitors withdrawn

HazMat Unit with breathing apparatus withdrawn

Swiss Federal Railways contact lines live again

Water tender TLF 2, fire protection and decontamination facility withdrawn

First train passes site of incident

Remaining emergency services equipment withdrawn, leaving only the water tank into which the ammonia had been discharged at the site. The contents are drained into the public sewer within about eight hours. use should it be required. The measurement group and police on monitoring and cordoning duties wore their normal working clothes but had their filter masks ready for use.

The following specifications (Table 3) give some details of two of the special items of equipment used:

\section{Experience}

Fortunately, incidents involving liquefied gases are very rare. Dealing with them requires not only specific technical knowledge in each case but also the use of special equipment, which can on no account be held by every HazMat Unit.

When an incident occurs, protection of the immediate environment and the safety of the emergency site must be given first priority. Following this, the use of special equipment must be agreed in detail with the organisations involved and the procedure to be taken, including contingency plans should problems occur (e.g • sudden leakage), must be planned in as fine a detail as possible.

All emergency personnel must then be informed in detail over the planned procedure, so that they can perform their tasks in awareness of the overall objectives.

As a rule, the work involved in this preparation will require considerably more time than the actual use of the equipment which follows.

Comprehensive checklists are necessary for the individual steps involved in using the equipment. The specialists involved must be familiarised with the use of these checklists, which can only be achieved by having carried out regular exercises.

The work must be supervised constantly and purposefully, and must also be recorded in writing.

Should concerns of safety or problems arise, the work must be immediately interrupted and the subsequent procedure specified by the officer in charge. Any changes made to the procedure must be advised to all personnel involved in the incident in good time.

The concentration of individuals dealing with an incident tends to flag with time. Whenever necessary, some of the personnel must be relieved in good time, but the longer the operation lasts, the more the supervision must be intensified.

The safety of local residents and inci- 
Table 3.

$\begin{array}{ll}\text { Liquefied gas pump (Fig. 3): } & \\ \text { Make, type: } & \begin{array}{l}\text { SIHI CEHY 4107/6 1F9AK4B4S, self-priming, } \\ \text { low NPSH required }\end{array} \\ \text { Capacity: } & \max .30 \mathrm{~m}^{3} / \mathrm{h} \\ \text { Total head: } & \text { approx. } 110 \mathrm{~m} \\ \text { Allowable pressure: } & 40 \text { bar } \\ \text { Temperature range: } & -40{ }^{\circ} \mathrm{C} \text { to } 120^{\circ} \mathrm{C} \\ \text { Casing pressure rating: } & \mathrm{PN} 25 \\ \text { Sealing technique: } & \mathrm{canned} \text { motor } \\ \text { Drive: } & \text { canned motor } \\ \text { Motor rating: } & 37 \mathrm{~kW} \\ \text { Casing gasket: } & \text { Teflon } \\ \text { Interlocks: } & \text { low level switch and low flow rate switch }\end{array}$

\section{Pressure hoses:}

Make, type:

Material:

Inner wall:

Nominal diameter:

Flanges:

Temperature range:

Operating pressure:

Vacuum rating:

Earthing: for liquefied gas to DIN 4815/3

NBR

homogeneously smooth

DN 50

DN 50 PN 40

$-40^{\circ} \mathrm{C}$ to $+70^{\circ} \mathrm{C}$

25 bar with a safety factor of at least 4

0.8 bar absolute
Butapal-SD DN050 PO50BUW high pressure hose

manufactured with an integral steel wire helix and copper braid to dissipate electrostatic charge

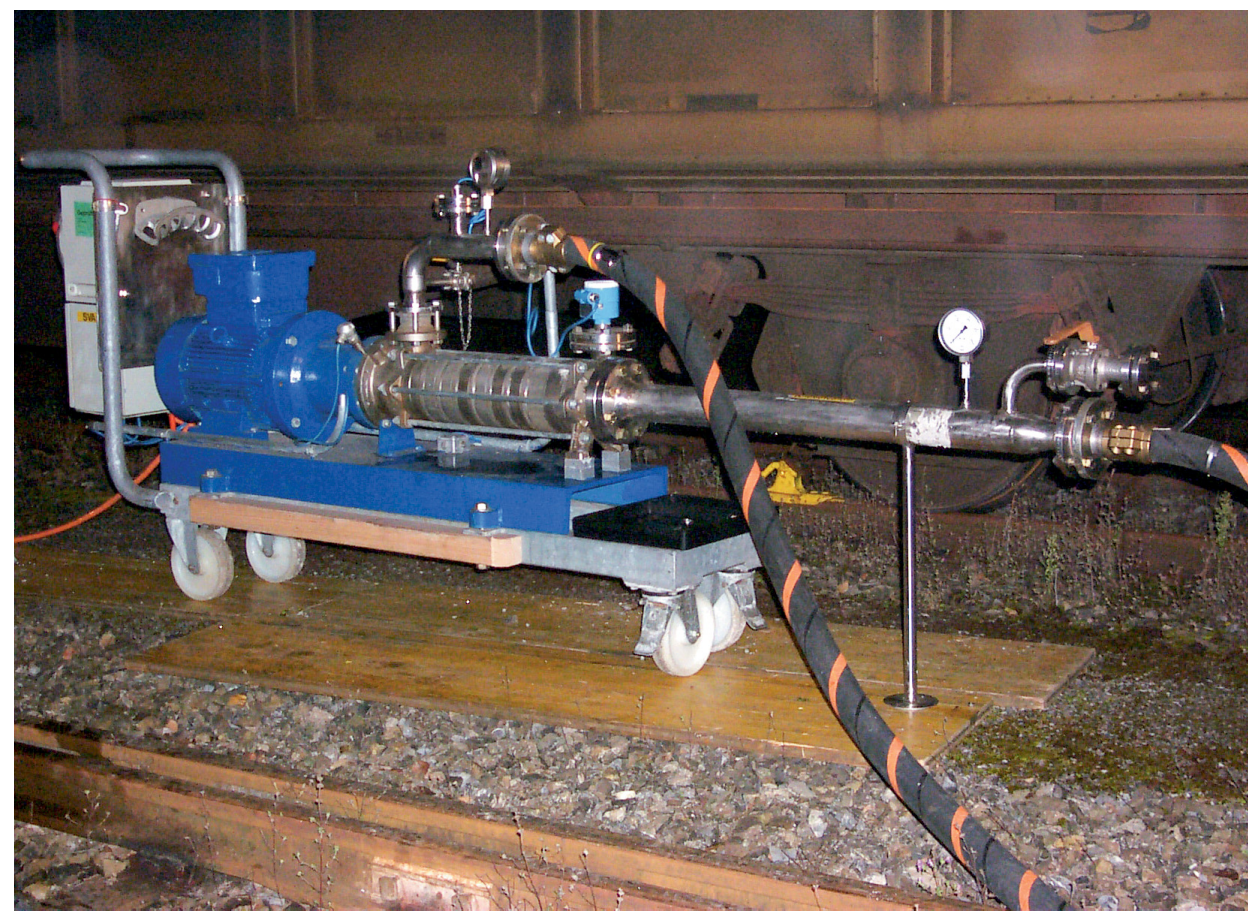

Fig. 3. Liquefied gas pump with suction hose connected with casing and pressure hose above. For technical specifications see text. dent personnel must always be given first priority.

The following points must therefore be taken into account during incidents involving liquefied gases:

- Should an incident occur, all work with liquefied gases must be left to specialists.

- These specialists and their special equipment must be called out in good time.

- Sufficient time must be allocated for making preparations and carrying out the operation.

\section{Training Facilities on the DNP Exercise Site}

our exercise site, which has been approved by the authorities responsible, offers various possibilities for training, and can also be rented by external emergency organisations and companies. The facilities on of fer include the following:

- Practical training with portable fire extinguishers.

- Extinguishing fires involving gases, liquids and solids (also suitable for firefighting and emergency rescue trains, as a rail track is only some $50 \mathrm{~m}$ away from the exercise ground).

- Demonstrations of BLEVE and boilover.

- Exercise container for breathing apparatus.

More detailed information is available at all times to anyone who is interested. Please contact the shift duty officer of our Works Fire Brigade: Tel.: +41 628662222 or $+41797639626$

Received: December 5, 2003 